\title{
The impact of cultural based activities in foreign language teaching at upper-intermediate (B2) level
}

\author{
Yakup Doganay \\ Faculty of Philology, Süleyman Demirel University, Almaty, Kazakhstan
}

Email address:

yakdoganay@yahoo.com

\section{To cite this article:}

Yakup Doganay. The Impact of Cultural Based Activities in Foreign Language Teaching at Upper-Intermediate (B2) Level. Education Journal. Vol. 2, No. 4, 2013, pp. 108-113. doi: 10.11648/j.edu.20130204.11

\begin{abstract}
This Study is conducted to find out the influence of cultural based activities in foreign language teaching through conducting number of lessons continued approximately 10 weeks in Language School at Süleyman Demirel University. We have tried to find out the attitudes of students towards teaching/learning foreign language through cultural based activities and the effects of these cultural based activities applied in English lessons on developing communicative and linguistic competence in L2. Among them were used: games, role plays, dialogues, discussions, comparisons of home and host cultures, video and authentic materials that can help and encourage students to sustain their interest and work. Through practicing various cultural based tasks and exercises, the students explored communicative skills. The tasks conducted both for the teachers' and students' insights into how cultural based activities can be used not only to develop students' confidence and language skills but also to expand their sense of awareness of intercultural concerns in L2.
\end{abstract}

Keywords: Intercultural Communicative Competence, Attitudes, Cultural Based Activities, Assessment, Lingua-Culture

\section{Introduction}

That culture and language are inseparable notions has been stated by numerous prominent scholars such as Wittgenstein (1980), Saussure (1966), Foucault (1994), Dilthey (1989), Von Humboldt (1876), Adorn (1993), Davidson (1999), Quine (1980) and Chomsky (1968). These are the names to come to mind when the issue is the relationship between language and culture from different points of views regarding language, human, mind and culture. The most well-known linguists dealing with the issue of language and culture are Sapir (1962) and Whorf (1956). In addition to the previous ones, the following researchers such as Laura (3), Kunanbayeva (1995), Jenkings (2008), Leveridge and Thanasoulas (2009) have also made precise contribution to this issue.

For a long time it has been argued that teaching a foreign language through lingua-cultural approach should be given the importance it deserves. Therefore, many scholars have paid plenty of attention to developing the notion 'intercultural communicative competence' and contribute ideas of implementing cultural based activities into process of foreign language teaching. With the works of scholars such as Byram (1989; 1994a; 1994b; 1997a; 1997b) and Kramsch (1988; 1993; 1996; 2001) people, involved in language teaching, have begun to understand the intertwined relation between culture and language. It is emphasized that without the use of cultural based tasks and activities, teaching a foreign language is inaccurate and incomplete. For L2 students, language study seems senseless if they know nothing about the cultural background of people who speak the target language. Learning a foreign language means a lot more than acquiring just grammatical structure and vocabulary of it. According to Bada (2000: 101), 'the need for cultural literacy in ELT arises mainly from the fact that most language learners, not exposed to cultural elements of the society in question, seem to encounter significant hardship in communicating meaning to native speakers.' In addition, nowadays the L2 culture is presented as an interdisciplinary core in many L2 curricula designs and textbooks (Sysoyev \& Donelson, 2002).

When we turn to the relationship between culture and language, we see some remarkable comments; to supply a satisfactory reply to the question of why teaching culture should be involved in language teaching. Kitao (2000) giving reference to several authors lists some of the benefits of teaching culture as follows:

- Studying culture gives students a reason to study the target language and can be a good motivational tool. 
- $\quad$ One of the major problems in language teaching is to enable students think in the language they learn.

- Providing access into cultural aspect of language, learning culture would help learners relate the abstract sounds and forms of a language to real people and places (Chastain, 1971).

- The role of motivation in ELT was proved by experts like Gardner and Lambert (1959, 1965, and 1972). In achieving high motivation, culture classes do have a great role because learners like cultural based activities such as singing, dancing, role playing, discussing about and doing research on countries and peoples, etc.

- The use of cultural based activities in language education increases learners' not only curiosity about and interest in target countries but also their motivation.

Beside these benefits, studying culture gives learners a liking for the native speakers of the target language. 'Studying culture, we could also learn about the geography, history, etc., of the target culture (Cooke, 1970). McKay (2003) contends that culture influences language teaching in two ways: linguistic and pedagogical. Linguistically, it affects the semantic, pragmatic, and discourse levels of the language. Pedagogically, it influences the choice of the language materials because cultural content of the language and the cultural basis of the teaching methodology are to be taken into consideration while deciding upon the language materials.

\section{Problem Statement}

The process and result of teaching a foreign language are affected by various factors such as the used approaches, methods, techniques, teachers, learners, motivation, environment, etc. Using the culture of the target language as one of the effective approaches and ways in teaching English is not an exception. However, it is given a poor consideration. Bearing in mind that 'cultural competence' is an integral part of 'communicative competence' or viceversa; teachers should create an atmosphere of a real English speaking society or environment through the use of lingua-cultural aspects. As Kramsch says: 'in class, culture is created and enacted through the dialogue between teacher and students, Through their dialogue, participants not only replicate a given context of culture, but because it takes place in a foreign language, it also has the potential of shaping a new culture.' (1993, p. 49). The main problem in foreign language education is that the educators cannot enable L2 students to use target language effectively and appropriately for intercultural communication. In this paper we would like to focus on how culture is viewed by students and also how the application of the cultural based activities influences the result of foreign language teaching/learning. So, the problem and aim of our investigation can be stated as follows:

What are the attitudes of learners towards using culture in English classes?

To what extend does the use of cultural based activities and tasks affect the progress, the students get, while studying English?

\section{Methodology}

\subsection{The Purpose of the Research}

The cultural content existing in language teaching has been discussed a lot. However, as far as we see these cultural content or cultural based activities have not been designed in course books enough and put into practice fully in foreign language teaching. So, the main purpose of this study is to find out the attitudes of students to using cultural based activities and tasks in classroom and also to figure out how they get progress and affected by the use of culture-based activities in teaching a foreign language (English).

\subsection{The Universe and the Sample}

This research took place in the spring term in 2012 at Süleyman Demirel University in Preparatory Course of Language School. The Preparatory Course at SDU is settled as follows: The language course lessons are divided into four subjects such as 'Main Course', 'Listening \& Speaking', 'Reading \& Writing' and 'Grammar'. The first one (main Course) focuses on the presentation and practice of language for effective communication in everyday social and workplace situations. Emphasis is on developing the four integrated language skills. Teachers develop students' accuracy, oral fluency and language appropriateness by practicing the language in real-life contexts. Therefore, the 'Main Course' subject was chosen to be ideal subject to make students get experiences by using different challenging activities to master the language through its culture and also mostly for having the main course book as one of the most useful source materials designed very neatly in general.

\subsection{Data Collection and Analysis}

This chapter aims to present the design, subjects, data collection procedure and data collection instruments of the study and data analysis. We have tried to make a both quantitative and qualitative research by literary review and collection of data from exams and questionnaires given to the students.

The data was obtained;

a) Applying questionnaires to the students in Language School at Süleyman Demirel University, consisting of three parts; first 8 YES/NO, second 3 open ended and third 6 evaluative questions. With YES/NO questions we aimed to find out how open the students were to, concerned with and what their attitudes were towards the culture of target language and whether they have some fears or doubts that teaching a foreign language through 
cultural based activities is a kind of cultural imperialism and assimilation. The second part, consisting of three open ended questions, which assisted us to find out more detailed data on the effectiveness of using culture and its implications in teaching a foreign language, and the third, including six questions, aiming to figure out how our students assess the cultural based activities and exercises, given post-experiment. These questionnaires research the answers to the question whether cultural-based exercises and activities have a positive impact on both attitudes of learners and foreign language teaching process and also results.

b) The participants, consisting of 80 students, were divided in to four groups, 2 control and 2 experimental. Experimental groups consisting of 18-22 students and control having 20-20 students in each group. Taking in to consideration that each teacher's application and use of cultural based activities differs, we especially chose two groups both for experiment and control. To get more reliable and valid results about their progress, students were given exams pre and post-experiment and total averages of their results were presented.

\section{Findings and Discussion}

As it has been mentioned before throughout two and half months we have had four groups; two experimental and two control groups. Considering the fact that developing 'communicative competence' for 'intercultural interaction' has become the major aim in teaching/learning L2 process, we tried to organize communicative activities that have culture in, most of which have been put into practice in the form of warm ups, discussions, speeches, dialogues, role plays and so on. Thus, the overall results indicate the usefulness of culture matters for the language learning groups as one of the leading ways of teaching a foreign language. According to the results, almost every respondent agrees that the use of cultural based activities affect the learning process in positive way. Students make clear that by learning some features of foreigners' behaviors depending on their cultural background different from those of the learners' it becomes easier and interesting to be involved in the current learning process. During the experiment it has been observed that cultural-based exercises and activities stimulate students to interact with each other, use the language tasks more efficiently.

As a result of the pre-experiment survey, the students admitted that they come across with tasks, connected to different cultural aspects, not very often but they understand the importance of culture in language learning. Through using the knowledge of culture of target language, they know how to survive in different life situations and behave properly. As one of the students says 'we should know is it acceptable or unacceptable, appropriate or not in stopping the bus in our way in order not to cause misunderstandings between two cultures'. Beside this, just a few number of the participant students had some doubts and fears like, it is a kind of assimilation, cultural imperialism, whether necessary or not and so on, about the use of cultural based activities in teaching English. In sum, we came to conclusion that most of the students are aware of different cultures but still they should be helped to master their knowledge through the professional monitoring and teaching process along with foreign language education. The table above clearly shows the interest of learners towards using cultural activities in learning a language and they enjoy being involved in this atmosphere as the vast majority of them gave positive responses each question.

Table 1. Number and percentages of the students answered with YES/NO

\begin{tabular}{|c|c|c|c|}
\hline & Ans. & N. Std & $\%$ \\
\hline Do you enjoy working with other students in groups? & YES & 70 & $\% 87.5$ \\
\hline Are you anxious or stressed when you work collaboratively with your peers? & NO & 72 & $\% 90$ \\
\hline Do cultural-based activities help you to overcome your anxiety or stress? & YES & 69 & $\% 86.3$ \\
\hline Do you like watching authentic extracts in target language about your culture? & YES & 79 & $\% 98$ \\
\hline Do you like watching authentic extracts in target language about other cultures? & YES & 78 & $\% 97.5$ \\
\hline Do you like behaving as if you are a foreigner in your dialogues? & YES & 70 & $\% 87.5$ \\
\hline Do you like searching other cultures in projects? & YES & 77 & $\% 96.3$ \\
\hline Do you like being involved in discussions about other cultures? & YES & 71 & $\% 88.7$ \\
\hline
\end{tabular}

a) The following questions were open ended where students expressed their ideas on how they liked to learn the language through culture and how well those activities helped them master the language. Most of them gave positive answers about the activities the teachers organized in their class. 'In your opinion, how did the cultural based activities improve your English?' was the first open question. Mainly, the great majority of students stated the active speaking abilities develop through the cultural based activities about different nations. They said that a student usually was never active until he/she was involved in an interesting task where they face any kind of everyday life situation. In the same way, they said that activities provided enjoyable and comfortable atmosphere. Second question was 'Can you name the most interesting cultural based activity you have ever done/involved? The answers to this question showed that they were all interested in finding out the family relationships of Kazakh, Russian, Turkish and English nations. Mostly, they liked the way that Kazakh and Turkish family member names are mostly the same and more than the family names in English culture and as well it was interesting for them to know how do Russian or 
English people call those family relations. The students here added that it made them learn more words connected to family members in all for languages. Finally, the third question to answer was: 'What other tasks or activities can you add to develop communicative skills?' Here the answers given proved that teaching/learning a foreign language by applying cultural based activities can be manifold and occur in different ways, not only in class but also at home watching some films, presentations, video, singing songs, practicing tongue twisters and so on. They mentioned that if the teachers select the right activity for each tasks and unit of the book it will be more beneficial.

b) The results got from the data about the students' exam grades are as follows;

Students' mid-marks at the beginning of project were as follows: as for experimental groups, first group 67, second group 71, mid-mark of two groups 69, as for control groups: first group 65, second group 70, mid-mark of two groups 67.5 , at the end of the project that cultural based activities have been implied were: as for experimental groups, first group 78, second group 82, mid-mark of two groups 80 , as for control groups: first group 72, second group 76, midmark of two groups 74. To interpret the results, the progress of control groups is around $9.6 \%$ as for the experimental groups it is approximately $15.9 \%$. Consequently experimental groups have got around \% 6.3 better progresses than control groups for the main course.

The results got from the data about the students' exam grades are as follows;

Table 2. The comparison of progresses of control and experimental groups.

\begin{tabular}{lllll}
\hline & Experimental Groups & Control groups \\
\hline$\#$ & $\mathbf{1}^{\text {st }}$ Group & $\mathbf{2}^{\text {nd }}$ Group & $\mathbf{1}^{\text {st }}$ Group & $\mathbf{2}^{\text {nd }}$ Group \\
Average Grade pre-experiment & 67 & 71 & 65 & 70 \\
Average Grade pre-experiment & 69 & & 67.5 & 76 \\
Average Grade post-experiment & 78 & 82 & 72 & 74 \\
Average Grade post-experiment & 80 & & 74 & \\
\hline
\end{tabular}

The progress can be noticed not only from the grades of written exams but overall participation throughout the lesson and willingness to do better. So, we can admit that the use of culture in ELT has a great motivational effect. However, the second group students didn't show such overwhelming results. By this fact we once again saw evidence that culture should be included in the language teaching curriculum. Here is a graph depending on the grades below:

c) The results inferred from the answers of the students of the post-experiment.
The purpose of the questionnaire was to find out the attitudes of students towards cultural-based (lingua-cultural and socio-cultural) communicative exercises and activities especially after the experiment. We asked six questions to be able to measure and understand to what extent their English learning have been effected, how they liked cultural based activities and exercises in language teaching/learning process. The learners were asked to evaluate the statements about the mentioned activities by the scale from 1 to 5 (1-strong disagreement, 5- strong agreement). The statements were as following:

Table 3. Number and percentages of the students evaluated the cultural based activities

\begin{tabular}{|c|c|c|c|c|c|}
\hline \# & trongly & Disagree & Neutral & Agree & Strongly agree \\
\hline $\begin{array}{l}\text { Involving cultural based communicative activities is } \\
\text { interesting. }\end{array}$ & $0(\% 0.00)$ & $6(\% 7.5)$ & $10(\% 12.5)$ & $42(\% 52.5)$ & $22(\% 27.5)$ \\
\hline $\begin{array}{l}\text { Group projects, group discussions, collaborative cultural based } \\
\text { activities and tasks are enjoyable }\end{array}$ & $0(\% 0.00)$ & $0(\% 0.00)$ & $9(\% 11.25)$ & $46(\% 57.5)$ & $25(\% 31.25)$ \\
\hline $\begin{array}{l}\text { Cultural based communicative activities and tasks improve my } \\
\text { English. }\end{array}$ & $0(\% 0.00)$ & $0(\% 0.00)$ & $8(\% 10)$ & $55(\% 68.75)$ & $17(\% 21.25)$ \\
\hline $\begin{array}{l}\text { I feel anxiety or stress in cultural based communicative } \\
\text { activities and tasks. }\end{array}$ & $10(\% 12.5)$ & $30(\% 37.5)$ & $29(\% 36.25)$ & $11(\% 13.75)$ & $0(\% 0.00)$ \\
\hline Watching extracts about home and host cultures are interesting. & $0(\% 0.00)$ & $5(\% 6.25)$ & $12(\% 15)$ & $32(\% 40)$ & $31(\% 38.75)$ \\
\hline $\begin{array}{l}\text { There should be extra and additional cultural based } \\
\text { communicative activities to the lessons. }\end{array}$ & $0(\% 0.00)$ & $0(\% 0.00)$ & $6(\% 7.5)$ & $56(\% 70)$ & $18(\% 22.5)$ \\
\hline
\end{tabular}

Concluding from the table 2 , the great majority of the students strongly and normally agree $(\%$ 80) and find cultural based communicative activities, collaborative cultural based activities and tasks (\% 88.75) and watching extracts about home and host cultures are interesting and enjoyable. Most of them (\% 90) believe that these kinds of activities and tasks improve their English. Just 10 students $(\% 12.5)$ stated that they feel anxiety or stress during 
cultural based communicative activities and tasks. A big number of students $(\% 92.5)$ agreed that there should be extra and additional cultural based communicative activities to the lessons.

\section{Conclusions and Implications for Education}

This study has checked and investigated the attitudes of learners towards using cultural activities and the overall impact of it on ELT. Teaching and learning a foreign language through culture-based activities is one of the most effective and interesting ways for presenting, practicing and improving the learner's communicative competence.

Cultural based activities contribute a lot in learning a foreign language if learners are given chance to practice the target language through its culture in a pleasant and friendly warm atmosphere. The role of cultural based activities in teaching a foreign language, in our case English, cannot be ignored because every cultural activity has shown plenty of advantages and effectiveness in ELT in many different ways. First of all, cultural activities bring a kind of fruitful atmosphere where students learn four skills through sharing information, discussing and interacting with each other. Secondly, cultural based activities involve learners in the task-based activities where the goal is to set and students do their best in order to compete with each other. The last but not the least: the main factor of using socio-cultural activities is that they bring real world context into the classroom, and enhance students' use of English in a flexible and communicative way. The main results of this research have implications for learners and teachers in the realm of teaching 'real' English.

While working with students of higher level we were provided with many possibilities where we may use different approaches and methods. To be able to implement them correctly into teaching process we should be aware of some individual diverse characteristics. Teachers should keep in mind that cultural activities must be changed time by time as students can get bored very easily and these activities should be organized following all demanded conditions. As it was stated by famous methodologists the effectiveness of the lessons depends not only on the thoroughly planned lesson but on the positive atmosphere created by the teacher through activities, in special, cultural activities.

Relying on the facts mentioned above, we can state that the use of cultural based activities is a manifold process in which you can learn a little bit of psychology of different cultural background because during this course you observe behaviors of students in different cultural situations.

The results of the data obtained from the data collection instruments showed that the cultural based activities have an effective influence on the development of linguistic competency of learners as well as communicative competency. Certainly, the activities would be successful if they are presented to students in understandable way which means that they must be planned step by step.

In general, aims and objectives of the study have been reached. It has been proved that using cultural based activities as tool or way in teaching the English language is appreciated by the majority of language learners. It has also became clear that students have positive attitudes towards cultural based activities. All language learners, in our case adult learners, are ready to fulfill tasks connected to culture both for fun and learning. In that case cultural based activities will be not just interesting for students to do but also bring the results you expect.

The idea of teaching a language through culture is not new to foreign language teachers. In many cases, teaching a language through cultural based activities has meant focusing a few lessons on holidays, customary clothing, folk songs, food, etc. Understanding the cultural context of day-to-day conversational conventions such as greetings, farewells, forms of addressing, thanking, making requests, and giving or receiving compliments means more than just being able to produce grammatical sentences. It means knowing what is appropriate to say to whom, in what situations, and it means understanding the beliefs and values represented by the various forms and usages of the language.

Culture can be fully or at least additionally incorporated as a vital component of language learning. Foreign language teachers should identify key cultural items in every aspect of the language that they teach. The activities should be planned according to the exact level of students whether it is low intermediate or high, in order to make them feel more confident while expressing their opinions on different cultural situations, otherwise the students will not manage the discussion. Students can be successful speaking in a target language if cultural issues are an inherent part of the curriculum.

Another point, we had to consider is the multicultural groups where each representative of different nations must be paid attention. For example, while introducing famous artists of different foreign countries do not forget to include those artists coming from the same country of your students. It will make students become pride of their nations and it can work as a motivational tool to continue the discussion activity.

The last but not least point to consider is the different cultural background of students. Before implementing some aspects of culture of a foreign language, in our case English, it is important for the teacher to take into consideration that some customs, traditions can be rude, humiliating or can be considered as abnormal by some students depending their origins especially, if we compare Christian and Muslim culture. For example, it might concern some specific vocabulary or behavioral pattern of the target culture which our student can find inappropriate. Therefore they can be forewarned about cultural and mentality diversity to provide openness of our students to different cultures or to overcome the cultural shock.

So, we came to conclusion that teaching language 
through culture can be profitable and fruitful but should be carefully planned and designed equally to other methods of teaching.

\section{Resume}

In this article the prominent pioneers have been reviewed first about relationship between culture and language first. After that, under the lights of their ideas, the impact of cultural based activities in foreign language teaching at one certain level has been checked out through some certain classroom instructions where these designed and adapted cultural based activities used and exams given to the students. The attitudes of both teachers and students towards the use of cultural based activities in foreign language teaching have also been investigated by giving them questionnaires.

\section{References}

[1] Adorn, T. (1993). The Culture Industry: Selected Essay on Mass Culture. Rutledge.

[2] BillGenk and EndogenBade. (2005). Culture in language learning and teaching.Turkey. University of Çukurova.

[3] Byram, M. (1997). Teaching and assessing intercultural communicative competence.

[4] Chomsky, N. (1968). Language and Mind. Harcourt Brace Jovanovich, Inc.

[5] Davidson, D. (1999). The Philosophy of Donald Davidson. (Ed) Lewis Edwin Hahn. Illinois: Open Court Publishing Company.

[6] Dilthey, W. (1989).Introduction to the Human Sciences: An Attempt to Lay a Foundation for the Study of Society and History. Wayne State University Press.

[7] Edward Sapir (1921). An Introduction to the Study of Speech. New York.

[8] Foucault, M. (1994).The Order of Things: Archaeology of the Human Sciences. USA: Vintage Books.

[9] Gardner, R. C., \& Lambert, W.E. (1959).Motivational variables in second language acquisition. Canadian Journal of Psychology, 13, 266-272.

[10] Gardner, R. C., \& Lambert, W. E. (1972).Attitudes and motivation in second language learning. Rowley, MA: Newbury.

[11] Humboldt, K. W. (1876). The heterogeneity of language and its influence on the intellectual development of mankind.

[12] Kitao, K. (2000). http://eric.ed.gov/PDFS/ED330214.pdf.

[13] Kramsch, C. (1993). Context and Culture in Language Teaching. Oxford University Press

[14] Kunanbayeva, S. (2005). Modern Foreign Language Education, Methodology and Theory, Dom Pechat, Almaty.

[15] Laura A, From Cognitive Linguistics to Cultural Linguistics, for publication in Slovo a smysl /Word and Sense (ISSN 1214-7915), University of North Carolina and University of Tromsø.

[16] McKay, (2003). Teaching English as an International Language: Rethinking goals and approaches.Oxford University Press.

[17] Quine, W. V. (1980). From a Logical Point of View: Nine Logico-Philosophical Essays. Harvard University Press.

[18] Richards, J. and Rodgers, T. (2002): Approaches and Methods in Language Teaching, Cambridge: CUP

[19] Sapir, E. (1962). Culture, Language and Personality.University of California.

[20] Saussure, F. (1966). Course in General Linguistics. Edited by Charles Bally, Albert Sechehaye collaboration with Albert Riedlinger. Translated by Wade Baskin.

[21] Sebnem Penbek, Dicle Yurdakul A. GuldemCerit. (2009). Intercultural Communicative Competence: A study about the Intercultural Sensitivity of University students based on their education and international experiences. Turkey, Izmir University of Economics.

[22] Sysoyev, P.V.\&Donelson L.R. (2004). Teaching Cultural Identity through Modern Language: Discourse as a Marker of an Individual's Cultural Identity.

[23] Wittgenstein, L. (1980). 'Culture and Value.' (Trans. by Peter Winch) Chicago: Chicago University Press. 84

[24] Whorf, B. L. (1956). Language, Thought, and Reality: Selected Writings of Benjamin Lee Whorf. (Ed) John B. Carroll. Cambridge: MIT Press. http://orvillejenkins.com/ethnicity/culturelearn.html,

[25] Orville Boyd Jenkins, EdD, PhD, Culture, Learning and Communication, First posted 1 April 2000, last updated 1 Febuary,2010.http://www.developingteachers.com/articles_t chtraining/culture1_dimitrios.htm,

[26] Dimitrios Thanasoulas, Language and Culture - a thesis, 2000-2009http://edition.tefl.net/articles/teachertechnique/language-culture/,

[27] Leveridge. N. A, the Relationship between Language \& Culture and the Implications for Language Teaching, TEFL.net. 